UNDER SURVEILLANCE 
THIS PAGE INTENTIONALLY LEFT BLANK 


\section{Under Surveillance}

Being Watched in

Modern America

RANDOLPH LEWIS

40

University of Texas Press

AUSTIN 
Copyright (C) 2017 by the University of Texas Press

All rights reserved

Printed in the United States of America

First edition, 2017

Requests for permission to reproduce material from this work should be sent to:

Permissions

University of Texas Press

P.O. Box 7819

Austin, TX 78713-7819

utpress.utexas.edu/rp-form

(0) The paper used in this book meets the minimum requirements of ANSI/NISO Z39.48-1992 (R1997) (Permanence of Paper).

\section{LIBRARY OF CONGRESS CATALOGING-IN-PUBLICATION DATA}

Names: Lewis, Randolph, author.

Title: Under surveillance : being watched in modern America /

Randolph Lewis.

Description: First edition. | Austin : University of Texas Press, 2017. |

Includes bibliographical references and index.

Identifiers: LCCN 2017003541

ISBN 978-1-4773-1243-8 (cloth : alk. paper)

ISBN 978-1-4773-1380-o (library e-book)

ISBN 978-1-4773-1381-7 (non-library e-book)

Subjects: LCSH: Electronic surveillance-Social aspects-United

States. | Social control-United States. | Privacy, Right of-United

States.

Classification: LCC TK7882.E2 L49 2017 | DDC 363.1/o63-dc23

LC record available at https://lccn.loc.gov/2017003541

doi: $10.7560 / 312438$ 